\title{
The Effect of Scientific Inquiry Learning Model Using on Student's Concept Knowledge and Science Process Skills in Senior High School
}

\author{
Evy Maria Br Meliala ${ }^{1}$, Eva Marlina Ginting ${ }^{2}$, Nurdin Siregar ${ }^{3}$ \\ \{evymariameliala@gmail.com\} \\ Department of Physic Education,Postgraduate Program,Universitas Negeri Medan ${ }^{1,2,3}$
}

\begin{abstract}
Study aimed to analyze the effect of scientific inquiry learning model on concept knowledge and science process skills in senior high school students. This research is a quasi experimental research with two group pre-test post-test design. The population of this research is all student of class XI MIA SMAN 1 Delitua (Senior High School), semester I academic year 2018/2019. Selection of sample is done by cluster random sampling that is XI MIA-1 as experiment class applied scientific inquiry learning and XI MIA-2 as control class applied conventional learning. Instrument used in this research is instrument of concept knowledge in essay form as much as 10 problem and instrument of science process skills in essay form as much as 10 problem which have been declared valid by expert team. Form the result of the study concluded that the first hypothesis test obtained t-counted $=2,92$ with $\alpha=0,05$ obtained $\mathrm{t}$-table $=2,00$. By comparing t-counted with $\mathrm{t}$-table turns $\mathrm{t}$-counted $>\mathrm{t}$-table, this means concept knowledge of students applying scientific inquiry model better than the student's concept knowledge with conventional learning. The second hypothesis obtained t-counted $=3,53$ with $\alpha=$ 0,05 obtained $t$-table $=2,00$. By comparing $t$-counted with $t$-table turns $t$-counted $>t$ table it means the science process skills of students applying scientific inquiry learning model is better than student's science process skill with conventional learning.
\end{abstract}

Keywords: Scientific Inquiry Learning Model, Concept Knowledge, Science Process Skills

\section{Introduction}

Based on the results of a preliminary study conducted by researchers on students and a physics teacher at SMAN 1Delitua 1, it was found that in starting the lesson the teacher rarely presents conceptual problems. The teaching and learning process prioritizes the completeness of the material and less optimizes students' learning activities to find their own concepts and use knowledge the concept he has to solve a problem, this shows that aspects of conceptual knowledge that students have is still lacking. The process of teaching and learning in the classroom tends to be analytical by focusing on decreasing physical formulas through mathematical analysis to solve problems, so students find it difficult to learn physics and questions that are trained by the teacher are very far from the real world. Practical activities to train students' science process skills are rarely implemented in the learning process, instead the teacher performs demonstration activities. Demonstrations are carried out because the teacher has the consideration that the demonstration activities do not spend time. The learning process 
is more dominated by conventional learning. In the implementation of the learning process, question and answer activities between teachers and students are also lacking. Students rarely ask questions and answer questions, there are even students who never ask questions or answer questions given by the teacher because students do not understand the subject matter delivered, so students become less active and feel bored following the ongoing learning process.

Based on the description of the preliminary study above, it can be concluded that, in the implementation of the learning process, it is necessary to have a scientific inquiry-based learning model that is able to encourage student activities, so that students are more active in following the learning process which is expected to influence students 'conceptual knowledge improvement and learning outcomes such as students' science process skills as well. will increase. Scientific inquiry-based learning model is a scientific inquiry learning model. According to Joyce (2009), "The core of the scientific inquiry learning model is to involve students in investigating the actual problem by exposing them to the investigation, helping them identify methodological or conceptual problems in the investigation and inviting them to design ways to overcome these problems ". Thus, students can find out how knowledge is built in the community of scientists. At the same time, students will also appreciate knowledge as a result of an exhausting research process and may also learn the limitations and advantages of current knowledge.

\section{Method}

This research was carried out at SMA Delitua 1 which is located at Jln. Education No. 1 Delitua, District of Delitua, Deli Serdang Regency, Indonesia, in class XI in the odd semester of 2018/2019 Academic Year.

The sample was taken randomly (cluster random sampling), which is class XI MIA-1 using the inquiry scientific learning model and class XI MIA-2 using conventional models.

This type of research is quasi-experimental and the research design was carried out with the pre-test post-test control group design.

Table 1.Pre-Test Post-Test control group design

\begin{tabular}{llll}
\hline Sample & Pre-test & treatment & Post-test \\
\hline Experiment & $\mathrm{Y}_{1}$ & $\mathrm{X}_{1}$ & $\mathrm{Y}_{2}$ \\
Control & $\mathrm{Y}_{1}$ & $\mathrm{X}_{1}$ & $\mathrm{Y}_{2}$ \\
\hline
\end{tabular}

$\mathrm{X} 1$ = Learning by using the Scientific Inquiry learning model; X2 = Learning by using conventional learning models; $\mathrm{Y} 1=$ The pre-test given before the treatment in the experimental class is the application of the Scientific Inquiry learning model and the control class which is the application of conventional learning; Y2 = Post-test given after treatment in the experimental class, namely the application of the Scientific Inquiry learning model and the control class by applying conventional learning.

Collecting data in this study using research instruments, namely tests of conceptual knowledge and science process skills of students. Data collection was carried out in two stages, the first stage was collecting students 'conceptual knowledge data and the second stage collecting data on students' science process skills. The research instrument was carried out in 
the form of a practical test in the form of student worksheets for science process skills and test essays for conceptual knowledge.

The statistic used in the study is the Lilliefors test to see normality, test the variance comparison to see homogeneity and t-test to see the effect.

\section{Result and discussion}

Students' conceptual knowledge learned by the scientific inquiry learning model shows better results than taught with conventional learning (Anggraini, et al, 2015, Suryani, et al, 2017, Suryanti, et al, 2015).

The cause of students' conceptual knowledge in the experimental class is better than the control class is because the scientific inquiry learning activities will support students to gain knowledge through several steps, namely observation, problem formulation, hypothesis preparation, data collection, and concluding. Students learn themselves in this learning to use investigate, solve and find solutions to problems given by teachers through investigations and discoveries through practical activities. This makes students more active in conducting investigations and discoveries. Practicum practices provide opportunities for students to experience themselves or do it themselves, following a process of observing an object, condition, or process of something. In practicum activities students will search and process research results to be used as knowledge, construct concepts meaningfully by connecting observations with theories that have been previously owned to solve a problem it faces. Joyce et al. (2009) state that the research process uses procedures - scientific procedures are scientific process skills carried out in a scientific activity. As stated by Siswono, et al. (2017) science process skills have a positive influence on the mastery of students' physics concepts which are proven through theoretical and empirical analysis. Science process skills can be demonstrated in a scientific activity and provide opportunities directly to students to be actively involved in learning to gain new knowledge or develop knowledge possessed by students. Suryani et al (2017) stated that the scientific inquiry model is suitable to be used to improve the Skill of the Science Process because essentially scientific inquiry teaches students to process information by using techniques that have been used by researchers, namely students faced with a scientific activity or experimentation through experiments that demand physical intellectual involvement of students. Active students will encourage the development of students' conceptual knowledge.

The second factor that causes conceptual knowledge of students in the experimental class is better than the control class because students are trained to ask and answer questions posed by the teacher. The scientific inquiry learning model is designed to bring students directly into the investigation process. Through the scientific model, students are expected to actively ask questions why something happened and then find and collect and process data to find answers to these questions. Learning that directs students to ask questions and answer questions according to Hersulastuti (2017) will direct students to have the ability to think critically, namely analysis, evaluation, conclusion, explanation, and self-reflection. The scientific learning model requires starting with presenting problems to students. As what was conveyed by Suryanti, et al (2015) Students who have good conceptual knowledge can be seen from the way he answers the question or in solving the given problem

The third factor that causes conceptual knowledge of students in the experimental class is better than the control class is because through the activities in the scientific inquiry learning 
model will encourage students to think critically. Critical thinking is a skill that must be trained to students because the goal of critical thinking is to achieve deep understanding. Safarani suggested learning objectives would be achieved well if students had adequate critical thinking skills. Practicum activities are one of the means to train critical thinking skills. Ngalimun (2016) that critical thinking students are expected to be able to propose various approaches in problem solving. Problem solving involves students in exploring and critically examining problems, ideas and arguments. by applying critical thinking skills in interpreting, analyzing, and evaluating. According to Joyce (2009), "The core of the scientific inquiry learning model is a learning model that involves students in research problems that are truly original by exposing them to the field of investigation, helping them identify conceptual or methodological problems in the field, and inviting them to designing ways to solve problems. From here, they can see how a science is created and built in the community of scientists. At the same time, they will value knowledge as a result of an exhausting research process and may also learn the limitations and advantages of current knowledge. Through practicum activities students will conduct scientific investigations and furthermore are expected to be accustomed to critical thinking, the same thing is conveyed by Syafitri (2016) there are differences in scientific thinking abilities between low and high levels of critical thinking, this is because students who think critically have a sense of wanting know high, get used to questioning everything, and have the ability to argue in terms of submitting a hypothesis. The ability or potential of individuals to think basically has been owned since the individual was born. The potential to think begins with the ability of each individual to guess or guess (hypothesize) of a problem. When an individual can prove his guess, he will arrive at a position that can encourage him to think further. Therefore, the potential to develop the ability to guess on each individual must be fostered. One way the teacher can do to develop the ability to guess (hypothesize) on each child is to ask various questions that can encourage students to be able to formulate answers temporarily or can formulate various estimates of possible answers to a problem being assessed, estimates as hypotheses not just any estimate , but must have a solid foundation of thinking, so that the hypothesis raised is rational and logical. In the scientific inquiry learning model, the above is an activity that arises during learning activities so as to provide meaning and fun for students because they find their own solutions to problems given by the teacher through investigations according to scientific steps. While conventional learning is learning that uses the teacher as the only source of learning, in the sense that the teacher is the holder of control and control in determining content, learning methods and assessing student learning outcomes. One of the weaknesses of this learning model is the success of student learning depends on the skills and abilities of the teacher, students are less involved in the learning process so that students feel bored.

Based on the description above it can be concluded that conventional learning is less able to improve students 'conceptual knowledge, and the scientific inquiry learning model is better in improving students' conceptual knowledge.

The science process skills learned by the scientific learning model show better results than students who are taught with conventional learning (Siswono, et al, 2017; Suryani, et al, 2017, Widyawati, et al, 2016).

The cause of science process skills in the experimental class is better than the control class is because the scientific inquiry learning model can provide a real and active experience through practicum activities. Learning activities involve students actively (student centre) to investigate problems presented on student worksheets. Scientific inquiry model learning activities train students to be skilled in obtaining and processing information through thinking activities by following scientific procedures. Angraini (2015) in his research found that there 
were differences in science process skills between students who were given a model of scientific inquiry learning and students who were given a direct instruction learning model. The average student process skills given scientific inquiry learning is 70.07 , and the average for students with direct instruction is 64.13. Through physics practicum activities will be easier to understand and understand because it is done directly so that they will know the truth there is a theory they get. Through practicum activities students will prove the concepts or theories that already exist and can experience the process or experiment itself then draw conclusions, so as to support students' understanding of the learning material.

The second factor that causes the science process skills of students in the experimental class is better than the control class is because the experiment can also be done to prove the truth. Ardani (2014) states that Experiment activities aim to train students 'thinking skills, develop students' scientific attitudes, and can train students to solve problems critically. Learning the model of scientific inqury learning invites students to criticize starting from problems, temporary answers, collecting and analyzing data and concluding answers to problems. As stated by Safarati (2017) From the results of the study showed there are differences in science process skills between students who are taught with the scientific inquiry inquiry model and direct instruction learning, the average pretest value of the class process skills direct instruction is 43.00 and the average posttest score is 75,14 . While the average value of the pretest of the scientific inquiry class is 44.50 and the average posttest score is 82.93. A good learning structure in the inquiry scientific inquiry model makes students have high thinking skills. It can be concluded that the scientific inquiry model uses the scientific inquiry learning model. can create better student process skills.

\section{Conclusions}

Knowledge of conceptual students learned by the scientific inquiry learning model is better than students who are taught with conventional learning; the science process skills of students who are taught with the scientific inquiry model are better than students who are taught with conventional learning.

\section{References}

[1]Moore, R., Lopes, J., 1999. Paper templates. In TEMPLATE’06, 1st International Conference on Template Production. SCITEPRESS.

[2]Smith, J., 1998. The book, The publishing company. London, 2nd edition.

[3]Anggraini, D., P., \& Sani, R., A., 2015, Analisis Model Pembelajaran Scintific Inquiry Dan Kemampuan Berfikir Kreatif Terhadap Keterampilan Proses Sains Siswa SMA, Jurnal Pendidikan Fisika ISSN 2252-732X, 4( 2), 201.

[4]Ardani, R., \& Suprapto, N.,2014, Pengaruh Model Pembelajaran Guided Inquiry Berbasis Eksperimen Terhadap Keterampilan Berfikir Kritis Siswa Pada Materi Fluida Statis Di SMA Negeri 1 Gedangan, Jurnal Inovasi Pendidikan Fisika (JIPF), 3(2), 167-173.

[5]Hersulastuti, 2017, Inquiry-Based Learning For Enhancing Critical Thinking Skills: Indonesian Students' Perspectives, 6th ELTLT International Conference Proceedings October 2017 UNNES.

[6]Joyce, B., Weil, M., \& Calhoun, E., 2009, Model's of Teaching, Pustaka Belajar, Yogyakarta, 8nd edition

[7]Ngalimun, 2016, Strategi dan Model Pembelajaran. Yogyakarta: Aswaja Pressindo. 
[8]Safarati,Harahap,M.,B.,Sinulingga, K., 2017, Pengaruh Model Scientific Inquiry Menggunakan Media PhET Terhadap Keterampilan Proses Sains Ditinjau dari Keterampilan Berpikir Kritis, Jurnal Pendidikan Fisika, 6(1).

[9]Siswono,H., 2017, Analisis Pengaruh Keterampilan Proses Sains Terhadap Penguasaan Konsep Fisika Siswa. Momentum, Physics Education Journal, 1(2), 83-90.

[10]Suryani, W., Harahap, M.,B., Sinulingga, K., 2017, The Effect of Scientific Inquiry Learning Model Using Mind Mapping and Critical Thinking Ability toward Student's Science Process Skills in Senior High School, IOSR Journal of Research \& Method in Education (IOSR-JRME), 7(5), 21-26.

[11]Suryanti,W.,E., Sudarman, Ismaimuza, D., 2015, Profil Pengetahuan Konseptual Siswa Kelas VII SMP Dalam Menyelesaikan Soal Persamaan Linear Satu Variabel Berdasarkan Tingkat Kemampuan Matematika. e-Jurnal Mitra Sains, 3(2), 51-60.

[12]Syafitri, R., Asyhar, R., Asrial. 2016, The Effescts of Inquiry Training Model and Critical Thingking to the Students's Scientific Thingking Skills on the Subject of Chemistry, jurnal Edu-Sains Volume, 5 (1).

[13]Wati,W.,Novianti. 2016 Pengembangan Rubrik Asesmen Keterampilan Proses Sains Pada Pembelajaran IPA SMP,JurnalIlmiahPendidikanFisika Al-BiRuNi, 05 (1) (2016), 131-140 